\title{
ANKYLOSING SPONDYLITIS IN A CANADIAN INDIAN POPULATION*
}

\author{
BY \\ J. P. GOFTON, H. S. ROBINSON, AND G. E. TRUEMAN \\ From the University of British Columbia and the Canadian Arthritis and Rheumatism Society, \\ B.C. Division
}

A survey for rheumatic disease in the Haida Indians of the Queen Charlotte Islands in 1962 (Robinson, Gofton, and Price, 1963) disclosed an unusually high prevalence of ankylosing spondylitis in the men. A relatively crude method of screening the population for ankylosing spondylitis was employed, and it was felt that a number of cases of the disease might have been overlooked. Therefore a second survey was undertaken in November, 1964, with the specific purpose of re-checking this population for the presence of ankylosing spondylitis. The methods and results of this more thorough survey are now presented.

\section{Method \\ Population Sample}

In both surveys all adult males were included who ordinarily resided in the two reserve communities. Some members have emigrated from the reserve in past decades, occasionally whole families, otherwise single men or women. There is no reason to believe that the presence or absence of ankylosing spondylitis played any part in these movements, i.e. it is unlikely that ankylosing spondylitis is concentrated in the parent community through the emigration of healthy members.

\section{Initial Survey, 1962}

During the course of a clinical examination for rheumatoid arthritis, 25 respondents with suggestive clinical findings, or with clinical ankylosing spondylitis, were subjected to an antero-posterior $x$ ray of the pelvis. On the basis of the clinical findings and these few $x$ rays, ten male cases of ankylosing spondylitis were diagnosed. This represented a prevalence of $2 \cdot 3$ per cent. of the combined male and female respondents, or $4 \cdot 2$ per cent. of the 238 adult male respondents over the age of 15 .

\section{Second Survey, 1964}

Of 239 adult males over the age of 15, 209 were examined-a completion rate of 87.4 per cent. Each respondent was examined by an experienced rheumatologist and an antero-posterior $x$ ray of the pelvis was obtained. The Rome criteria for the diagnosis of

*Through the assistance of Federal Health Grant No. 609-7-48 and the Canadian Arthritis and Rheumatism Society, B.C. Division. ankylosing spondylitis (Kellgren, 1962) were applied and a point prevalence estimate was derived. These criteria are reproduced below.

\section{Rome Criteria-Ankylosing Spondylitis}

The following criteria should be used for the diagnosis of ankylosing spondylitis:

(1) Low back pain and stiffness of over 3 months' duration which is not relieved by rest.

(2) Pain and stiffness in the thoracic region.

(3) Limited motion in the lumbar spine.

(4) Limited chest expansion.

(5) A history or evidence of iritis or its sequelae.

(6) $X$ ray showing bilateral sacro-iliac changes characteristic of ankylosing spondylitis (this would exclude bilateral osteo-arthrosis of the sacro-iliac joints).

The diagnosis is definite if four of the five clinica criteria are fulfilled or if criterion No. 6 and one other criterion are fulfilled. The number of persons fulfilling each separate criterion or combination of criteria shall be stated to demonstrate the full gradient of disease.

\section{Results}

The Table (overleaf) shows the full range of positive findings.

The $x$ rays were graded by two groups of observers, according to the recommendations of the Rome Symposium on Population Studies (Kellgren, 1962), as outlined in the "Atlas of Standard Radiographs of Arthritis" (C.I.O.M.S., 1963).

The Vancouver interpretation (V) represents the agreement of the three authors, achieved at a joint reading session where different opinions were reconciled. This session was preceded by an individual grading by each observer. Most difficulty was found with minimal degrees of abnormality.

The Phoenix (P) interpretation was arrived at by a similar process, representing the reconciled grading of three observers (J. S. Lawrence, P. H. Bennett, and J. P. Gofton).

The Rome criteria are applied to the data in the Table, using each set of $x$-ray gradings in turn. Differences in grading between the two groups of observers does not alter the prevalence defined by the Rome criteria. 
TABLE

POSITIVE FINDINGS

\begin{tabular}{|c|c|c|c|c|c|c|c|c|c|c|c|}
\hline \multirow{3}{*}{$\begin{array}{l}\text { Age } \\
\text { Group } \\
\text { (yrs) }\end{array}$} & \multirow{3}{*}{$\begin{array}{l}\text { Total } \\
\text { Cases }\end{array}$} & \multirow{3}{*}{$\begin{array}{l}\text { Q. } \\
\text { Code } \\
\text { No. }\end{array}$} & \multirow{3}{*}{$\begin{array}{cccc}\begin{array}{c}\text { Clinical } \\
\text { Criteria }\end{array} \\
1223 & 4.5\end{array}$} & \multicolumn{2}{|c|}{$\begin{array}{c}\text { Prevalence by } \\
\text { Vancouver } X \text {-ray } \\
\text { Interpretation (V) }\end{array}$} & \multicolumn{2}{|c|}{$\begin{array}{c}\text { Prevalence by } \\
\text { Phoenix } X \text {-ray } \\
\text { Interpretation (P) }\end{array}$} & \multicolumn{4}{|c|}{ Additional Data } \\
\hline & & & & $\begin{array}{c}X \text {-ray } \\
\text { Grade }\end{array}$ & \multirow{2}{*}{$\begin{array}{c}\text { Rome } \\
\text { Criteria } \\
\text { Total }\end{array}$} & $\begin{array}{l}X \text {-ray } \\
\text { Grade }\end{array}$ & \multirow{2}{*}{$\begin{array}{c}\text { Rome } \\
\text { Criteria } \\
\text { Total }\end{array}$} & \multirow{2}{*}{$\begin{array}{c}\text { Ankylosing } \\
\text { Spondylitis } \\
\text { found } \\
\text { in } \\
1962\end{array}$} & \multirow{2}{*}{$\begin{array}{c}\text { Peripheral } \\
\text { Joint } \\
\text { Disease } \\
\text { on } \\
X \text { ray }\end{array}$} & \multirow{2}{*}{$\begin{array}{l}\text { Rheumatoid } \\
\text { Factor } \\
\text { Positive } \\
\text { (1962) }\end{array}$} & \multirow{2}{*}{$\begin{array}{c}\text { Decade } \\
\text { Prevalence } \\
\text { (per cent.) }\end{array}$} \\
\hline & & & & $0-12234$ & & $\begin{array}{llll}0-1 & 2 & 3 & 4\end{array}$ & & & & & \\
\hline$\overline{15-24}$ & 62 & $\begin{array}{l}519(1) \\
151 \\
383\end{array}$ & * & $*$ & $\begin{array}{l}2 \\
1 \\
0\end{array}$ & $\begin{array}{l}* \\
*\end{array}$ & $\begin{array}{l}2 \\
\mathbf{0} \\
1\end{array}$ & & & + & $1 \cdot 6$ \\
\hline $25-34$ & 32 & $274(5)$ & $*$ & * & 2 & * & 2 & & & & $3 \cdot 1$ \\
\hline$\overline{35-44}$ & 31 & $\begin{array}{r}43 \\
119 \\
459\end{array}$ & $* *$ & * & $\begin{array}{l}3 \\
2 \\
1\end{array}$ & * & $\begin{array}{l}3 \\
2 \\
1\end{array}$ & + & & & $6 \cdot 4$ \\
\hline$\overline{45-54}$ & 34 & $\begin{array}{l}458 \\
506 \\
440 \text { (2) } \\
284\end{array}$ & $* * * *$ & * & $\begin{array}{l}3 \\
5 \\
1 \\
0\end{array}$ & $\begin{array}{r}* \\
*\end{array}$ & $\begin{array}{l}3 \\
5 \\
1 \\
1\end{array}$ & + & & & $5 \cdot 9$ \\
\hline$\overline{55-64}$ & 31 & $\begin{array}{l}464 \\
488 \\
443\end{array}$ & ***** & ${ }^{*} *$ & $\begin{array}{l}2 \\
6 \\
2\end{array}$ & $\begin{array}{l}* \\
* \\
*\end{array}$ & $\begin{array}{l}2 \\
6 \\
2\end{array}$ & + & $\begin{array}{l}+ \\
+\end{array}$ & & $9 \cdot 7$ \\
\hline$\overline{65-74}$ & 11 & $\begin{array}{l}271 \\
332 \\
505 \\
320(3)\end{array}$ & $\begin{array}{llllll} & * & * & * & * & \\
* & * & * & * & * \\
* & * & * & * & * & \\
& & & & & * \\
& & & & \\
\end{array}$ & $\begin{array}{l}* \\
* \\
*\end{array}$ & $\begin{array}{l}5 \\
6 \\
6 \\
1\end{array}$ & $\begin{array}{l}* \\
* \\
*\end{array}$ & $\begin{array}{l}5 \\
6 \\
6 \\
1 \\
\end{array}$ & $\begin{array}{l}+ \\
+ \\
\end{array}$ & $\begin{array}{l}+ \\
+ \\
+ \\
+\end{array}$ & $\begin{array}{l}+ \\
-\end{array}$ & $27 \cdot 3$ \\
\hline $75+$ & 8 & $141(4)$ & $* * * *$ & $*$ & 5 & $*$ & 4 & + & + & & $12 \cdot 5$ \\
\hline$\overline{\text { Total }}$ & 209 & & 86986 & $\begin{array}{llll}3 & 7 & 3 & 6\end{array}$ & $13+$ & $\begin{array}{llll}3 & 6 & 2 & 8\end{array}$ & $13+$ & 6 & 6 & 2 & \\
\hline
\end{tabular}

$\dagger 13$ definite cases (6.2 per cent. of the total of respondents) by either (V) or (P) grading

(1) New case-onset after 1962 survey.

(2) Classical Grade 4 sacro-iliac joints. No clinical symptoms or signs in 1964. 1962 records stated he had various peripheral joints swollen over 5-year period at age 16-21 yrs.

(3) Non-respondent in 1962.

(4) Clinical definite disease, calcified ilio-lumbar ligaments.

(5) Unilateral Grade 4.

Differences involving Grade 1 (suspicious but negative) and Grade 2 (definite abnormality) did not influence the prevalences for lack of supporting positive clinical data. In this sense the clinical criteria may "protect" the definition of disease from overly sensitive $x$-ray interpretation.

Case 141 is an interesting exception. This elderly man has clinically definite ankylosing spondylitis but the sacroiliac joints are not clearly ankylosed and might be interpreted as showing sclerotic changes of old age only. By clinical criteria alone he would be scored as definite by the Rome criteria.

Case 440 shows Grade 4 ankylosis of the sacro-iliac joints but provided no supporting clinical criteria. This may reflect disease confined to the pelvis in a reticent patient.

\section{Comparison Between 1962 Survey and 1964 Survey}

In 1962, ten cases of ankylosing spondylitis were diagnosed. In the 1964 survey seven of these were available, three having died. These seven cases were re-examined and six were confirmed as having
Rome Criteria Prevalence-6.2 per cent. True Prevalence (Add Q 440) -6.7 per cent.

One female Haida is known to have active ankylosing

The female population was not surveyed for this disease

ankylosing spondylitis. The remaining case, con sidered to be definite in 1962, was scored only as doubtful in 1964.

In 1964, seven additional cases were found by the more careful study. Had we relied upon the screene? ing study only we should have under-estimated the true prevalence of disease by almost one-half.

In 1962 the point prevalence of ankylosing spondy litis in adult males was $4 \cdot 2$ per cent. of 238 respondents. In 1964 the prevalence was $6 \cdot 2$ per cento of 209 respondents using the Rome criteria. If one adds the additional unequivocal case passed over by the Rome criteria the prevalence is increased to 6.7 per cent.

If the total adult male population at risk (239) is considered, the minimal point prevalence of ankylosing spondylitis is $5 \cdot 8$ per cent.

\section{Discussion}

Ankylosing spondylitis is usually considered to bह a disease of low prevalence and few studies have beerf directed specifically towards it. Most previouso 
estimates of prevalence have not exceeded 1 per cent. of the adult population (Robinson and others, 1963). From our experience it is apparent that a specific search will uncover cases overlooked by a screening method and the actual prevalence in other populations may be higher than prevailing estimates. It is not certain, therefore, that the true difference between the Haidas and other peoples is as great as it appears to be. However, the Haida prevalence is very high, exceeding the prevalence of rheumatoid arthritis in the population (Gofton, Robinson, and Price, 1964)-definite RA 1 per cent. females, 0.8 per cent. males; definite plus probable RA 2 per cent. females, $2 \cdot 1$ per cent. males. A meaningful biological disparity in the occurrence of ankylosing spondylitis is strongly suggested.

An unusually high prevalence of sacro-iliac changes, often indistinguishable from those associated with classical ankylosing spondylitis, is found in patients with psoriasis, ulcerative colitis, and Reiter's syndrome. No case of any one of these diseases was diagnosed by the clinicians in either the 1962 or the 1964 survey. An inquiry among physicians who ordinarily care for these people, followed by a search of hospital records, has failed to disclose a single case of psoriasis or ulcerative colitis in this population over the last 10 or 15 years. This would be sufficient evidence to conclude that these people do not have an extraordinary incidence of psoriasis or ulcerative colitis, although it would not exclude the possibility that either of these diseases may exist sporadically. There is little or no useful information on the frequency of Reiter's syndrome. The Haidas are naturally reticent in their description of symptoms and previous illnesses of this nature would be easily forgotten.

Of the thirteen cases of ankylosing spondylitis uncovered in this survey by using the Rome criteria, one had severe generalized disease of peripheral joints including the hips. In five, erosions were found on $x$ rays of the hands and feet, usually of minimal degree. The remaining seven cases had disease apparently confined to the pelvis and spine. None of the cases of rheumatoid arthritis discovered in 1962 showed significant changes in the sacroiliac joints. None of the thirteen cases of ankylosing spondylitis found in this survey had clinical evidence of peripheral disease which could be confused with rheumatoid arthritis; none fulfilled the A.R.A. criteria for definite rheumatoid arthritis. The presence of minor but typical erosive disease in the hands and feet of these five respondents was noted in a survey for rheumatoid arthritis in 1962. At that time these were considered to be isolated erosive changes of an unexplained nature, no other features of rheumatoid arthritis being present. The finding of erosions in the periphery in surveys for rheumatoid arthritis should take account of the possible contribution from undiagnosed ankylosing spondylitis.

These findings recommend further studies of the prevalence of ankylosing spondylitis, with methods specifically designed to gather a full spectrum of data. A survey is planned of another north-west coast Indian group in an attempt to discover if the high prevalence is characteristic of the region, or is localized to the population on the Queen Charlotte Islands.

From evidence so far assembled ankylosing spondylitis may prove to be a more rewarding disease for epidemiological studies than rheumatoid arthritis. Additional information on the comparatively high frequency of sacro-iliac disease in the Haidas is described in a subsequent paper.

\section{Summary}

A careful survey of adult Haida Indian males for ankylosing spondylitis disclosed a point prevalence of definite disease of 6.2 per cent, the disease being defined by the Rome criteria. This prevalence is markedly higher than previous estimates in other communities. It is unlikely to be related to psoriasis or Reiter's syndrome.

\section{REFERENCES}

C.I.O.M.S. (1963). "Epidemiology of Chronic Rheumatism", vol. 2, "Atlas of Standard Radiographs of Arthritis". Blackwell, Oxford.

Gofton, J. P., Robinson, H. S., and Price, G. E. (1964). Ann. rheum. Dis., 23, 364.

Kellgren, J. H. (1962). Bull. rheum. Dis., 13, No. 3, p. 291.

Robinson, H. S., Gofton, J. P., and Price, G. E. (1963). Ann. rheum. Dis., 22, 232.

La spondylarthrite ankylosante dans une population indienne canadienne

RÉSUMÉ

Une enquête soigneuse sur la fréquence de la spondylarthrite ankylosante parmi les mâles adultes Indiens Haida révéla que cette maladie "définie"-selon les critères de Rome-survenait en 6,2 pour cent d'entre eux. Cette incidence est fort supérieure à celle trouvée dans d'autres communautés. Il est peu probable qu'il y ait un rapport quelconque avec le psoriasis ou le syndrome de Reiter.

\section{Espondilartritis anquilosante en una población india canadiense \\ Sumario}

Una investigación cuidadosa de varones adultos entre los indios Haida en busca de espondilartritis anquilosante reveló una incidencia de la enfermedad "definida" en un 6,2 por ciento de ellos, definiéndose la enfermedad por los criterios de Roma. Esta incidencia es considerablemente mayor que las estimadas previamente en otras comunidades. Esto parece no tener relación con psoriasis o el síndrome de Reiter. 